\title{
KDY NENÍ TEOLOGICKÁ ETIKA TEOLOGICKÁ: PROBLÉMY V ČESKÉ TRADICI MORÁLNÍ TEOLOGIE
}

\author{
LIB O R O V E Č K A
}

\section{Smysl otázky}

$\mathrm{J}_{\mathrm{e}}$ e teologická etika skutečně teologická? ${ }^{1}$ Tato otázka působí na první pohled snad překvapivě, teologická etika je přece obor teologie; přesto je to ale otázka naprosto oprávněná. Existovaly a existují totiž různé tradice morálně teologického myšlení, z nichž některé přísně vzato nárok teologičnosti splňují jen částečně. Ne vždy měla morální teologie skutečně teologický charakter a mnohdy byla spíše či částečně projevem lidské moudrosti či lidské spekulace, která se sice vyjadřovala pomocí náboženských či teologických výrazů, ale stavěla víc na lidské myšlence než na slově Božím.

Toto pojednání si klade za cíl prozkoumat, jak se tato problematika jeví zejména, i když ne výlučně, v české teologické tradici, zvláště nedávné doby.

Co vlastně je ona „nedávná“ česká morální teologie? Po roce 1989 vyšla $\mathrm{v}$ naší republice celá řada morálně teologických publikací zahraničních autorů, ale jen dosti krátká řada knižních publikací teologů českých. ${ }^{2}$ Nikdo z těchto českých morálních teologů necituje v knižních publikacích nikoho z dřívějších moralistů $\mathrm{z}$ doby před nástupem komunismu, kontinuita teologického vývoje byla komunistickou totalitou přerušena. Prakticky poslední teologické publikace a časopisecké články vyšly v roce 1948, např. poslední číslo týdenního teologického časopisu Dobrý pastýr vyšlo příznačně 29 . února 1948.

Tato přerva ovšem nenastala pouze z důvodů politických, nýbrž i z důvodu teologického a církevního vývoje. Morální teologie pěstovaná v ob-

1 Pojmy „teologická etika“ a „morální teologie“ užíváme v tomto textu ve stejném významu bez rozlišení.

2 Oněmi českými publikujícími morálními teology jsou zejména Albert Beneš, Aleš Caha, Oto Mádr, Josef Petr Ondok, Jiří Skoblík. 
dobí před II. vatikánským koncilem, tedy pro nás více méně do roku 1948, měla značně jiný charakter než teologie po koncilu. Morální teologie, kterou můžeme zjednodušeně označit jako předkoncilní, výrazně ovlivňovaná snahou o obnovení tomismu a scholastiky v 19 . století, ${ }^{3}$ byla značně orientována na filosofickou spekulaci. Její snahou bylo obhajovat nauku vyjádřenou $\mathrm{v}$ oficiálních církevních dokumentech druhé poloviny 19. a počátku 20. století, které také argumentovaly více racionální spekulací než odvoláním na víru. ${ }^{4}$ Toto pojetí morální teologie propojovalo teologii a filosofii, ovšem pouze na „domácí půdě“, nebot mimo katolický prostor nebylo respektováno: jiná než křestanská resp. katolická filosofie je nebrala v úvahu a rovněž tato katolická filosofická morální teologie se od poznatků jiných oborů distancovala. ${ }^{5}$

Podle nepřímých výroků této předkoncilní teologie mohl člověk skrze své rozumové schopnosti př́mo poznávat Boha. K této teologické koncepci byli katoličtí teologové podněcováni církevními dokumenty, které dokonce mluvily o možnosti rozumovou cestou z viditelného díla stvoření dokázat Boží existenci. ${ }^{6} \mathrm{O}$ to mnozí katoličtí filosofové usilovali, avšak jejich úsilí nemůžeme ztotožňovat s křestanskou či katolickou teologií, která staví na Božím zjevení přijímaném ve víře. Náboženskou víru pak nelze ztotožnit s racionální spekulací.

Hranice mezi filosofií a přirozeným poznáním Boha na jedné straně a teologií opírající se o náboženskou víru na straně druhé nebyla ve scholastice ani v novoscholastice 19. a 20. století tak jasně narýsovaná, jak je tomu v novověkém filosofickém a teologickém myšlení. Čeští mo-

LEV XIII. Aeterni patris 1979. DS 3139-3140.

4 NOVOTNÝ, Josef. Mravnost a náboženství: obrana základů katolické mravouky oproti moderni proudům ethickým. Hradec Králové: Tiskové družstvo, 1921. V tomto apologeticky laděném spisu se Novotný snaží racionální argumentací dokázat, že moderní filosofické a vědecké poznání nemá pravdu a že pravdu má jedině nauka katolické církve. Není to ovšem výzva k víře, nýbrž výzva k přijetí autority Boha a jeho církve a její nauky.

5 Podobně tomu bylo i v německy a anglicky mluvícím prostoru. Srov. CORETH, Emerich - WALTER, M. Neidl - PFLIGERSDOFFER, Georg. Christliche Philosophie im katholichen Denken des 19. und 20. Jahrhunderts. Sv. 2. Graz: Styria, 1988, s. 565: „Im Vordergrund steht das Bemühen um die Neubelebung der hochmittelalterlichen bzw. spät- und barockscholastischen Philosophie. [...] Das Verhältnis zum modernen Denken gestaltet sich hingegen zum überwiegenden Teil negativ. Die Apologetik gibt den Ton an. Mehrere Neuscholastiker zählen sogar zu den aktiven Betreibern der antimodernistischen Kampagne." Podobně viz s. 739nn. o situaci neoscholastiky v anglicky mluvících zemích.

6 DS 3538. Viz též NOVOTNÝ, Josef. Mravnost a náboženství, s. 10: „Existence Boha je faktem nesporným.“ „Není místa, aby obšírněji byla zde dokazována existence Boha..." 
ralisté jako by byli částečně žili ve středověkých myšlenkových schématech. V morální teologii rovněž byla patrná snaha o nadčasový a nadsituační pohled na etická témata a aktuální etické otázky do ní pronikaly jen omezeně. ${ }^{7}$ Např. etické otázky vyvolávané událostmi první i druhé světové války reflektovala jen velmi málo, pokud vůbec.

Zároveň byla tato česká morální teologie nereflektovaně závislá na situaci ve společnosti, ve které vznikala, tedy v Rakousku-Uhersku, v Československé republice a v Protektorátu Čechy a Morava. Do jaké míry byla ovlivňována situací za protektorátní totality, je ovšem těžké prokázat, nebot' to zřejmě byl vliv pouze negativní, znemožňující svobodné publikování. Ale přesto: Pokud se zřekla reakce na nové „válečné“ a „okupační“ otázky, nebot by jinak vůbec nemohla být publikována, dávala svým čtenářům nepř́mo najevo, že takové otázky vůbec nejsou, nebo že ji nezajímají. A bud'to ji skutečně nezajímaly, z čehož ji lze vážně podezírat, nebot́ absenci nových otázek nutně vyvolaných válečnými událostmi musíme konstatovat i v publikacích uveřejněných po válce, nebo to byl jen vnucený postoj, který ale čtenáři nepochybně museli považovat za upřímný. ${ }^{8}$

\section{Slepé uličky teologie}

Co to znamená, že teologická etika by měla být teologická? V souladu s obvyklou definicí teologie by měla být uspořádanou naukou vycházející z rozumového poznání a z Božího zjevení přijímaného ve víře pěstovanou na půdě církve. Tento evidentní požadavek však nebyl vždy naplňován. Také v české teologické tradici nacházíme i v dobách ne př́liš vzdálených příklady morálně teologických systémů, které bez pochyby jsou uspořádanou naukou a bez pochyby vycházejí z racionálního poznání, avšak je pochybné, do jaké míry staví na víre a vycházejí i z Božího zjevení.

Snadno může dojít k nedorozumění $v$ tom, že se teologická etika zaměňuje s jinou disciplínou či oblastí poznání, která sama o sobě není morální teologií, což pak vyvolává dojem, že teologií není ani morální teologie. Nebo se předkládá argumentace, jež se sice vyjadřuje $\mathbf{v}$ teologických pojmech, avšak ve skutečnosti nemluví o moralitě. Uved'me nyní př́klady takových teologických slepých uliček z minulosti české morální teologie.

7 Např. VODIČKA, Timotheus. Principy sociálni ethiky. Sv. I-III. Olomouc: Krystal, 1945, s. 10. Vodička zdůrazňuje, že sociální nauka církve se nemění a od dob středověku resp. Tomáše Akvinského opakuje stále stejnou nauku.

8 Např. DACÍK, Reginald M. Mravouka. Olomouc: Dominikánská edice Krystal, 1946. Dacík ve své po válce publikované knize nebere válečné a okupační události vůbec v úvahu. 
Písmo a filosofická spekulace. Např. podle Antonína Vřeštála „poměr mezi Bohem Stvořitelem a člověkem, tvorem rozumným, nutně toho vyžaduje, aby člověk život svůj mravní uspořádal dle řádu Bohem mu stanoveného. Nemůžet́ člověk jinak cíle svého (blaženosti své) dosíci, leč plněním povinností mu uložených, a to povinností k Bohu, k sobě, k bližnímu. Výklad o těchto povinnostech lidských nazýváme mravoukou po případě mravovédou čili ethikou. Mravouka jest tedy podstatnou částí našeho (a každého) náboženství. “9 Tyto úvodní věty předznamenávají charakter celého tohoto Vřeštálova díla. Jejich stěžejní pojmy jsou: Bůh Stvořitel, člověk - tvor rozumný, nutnost, mravní život, Bohem stanovený řád, cíl - blaženost, plnění uložených povinností, výklad o povinnostech - mravouka. Některé tyto termíny se opírají o Boží zjevení, jiné vycházejí z filosofické spekulace, zejména: nutnost, cíl - blaženost, plnění uložených povinností. Tato filosofická spekulace však je v rozporu s tím, co předkládá Písmo.

Hned na samém počátku Geneze nacházíme zcela jinou teologickou konstrukci, a to koncepci Božího daru, který Bůh dává člověku bez jakéhokoliv požadavku, bez ukládání povinností a také bez stanovování cíle člověka, totiž blaženosti. Tu přece člověk už má, tu mu Bůh bezprostředně dává, vždyt' ona podstatně spočívá ve společenství s Bohem. Platí při tom jediné omezení: Chce-li člověk to, co od Boha dostal, mít, chce-li si to udržet, nesmí to sám zničit tím, že by chtěl odvrhnout Boha a posadit se sám na jeho trůn. Blaženost, kterou má, může mít pouze s Bohem, ne proti Bohu. Podstatou biblického poselství není stanovení povinností, které člověk musí splnit jako podmínku dosažení věčné blaženosti, nýbrž zvěstování spásy, kterou nám Bůh dává resp. už dal - vždyt' dle Geneze člověku byl dán život v ráji.

To je základní biblická morální koncepce. Ani líčení pádu do hříchu, ztráty rajské blaženosti a pozemského plahočení ji neruší. To, co od Boha dostáváme, je jeho svobodný, námi lidmi nezasloužený dar, který si nemůžeme na Bohu vymoci žádným způsobem, ani plněním povinností. Ospravedlnění člověka je dílem Božím. ${ }^{10}$ Člověk svou hřišnou vzpourou sice Boží dílo spásy a blaženosti narušil, ale nezničil. Vřeštálova myšlenka o plnění uložených povinností jako o cestě, jak lze dosáhnout věčné bla-

9 VŘEŠŤÁL, Antonín. Katolická mravouka. Sv. I. Praha: Dědictví sv. Prokopa, 1909, s. 3.

10 Srov. Společná deklarace Svétové luterské federace a Katolické církve o nauce o ospravedlnéni $\mathrm{z}$ 31. 10. 1999. <http://www.vatican.va/roman_curia/pontifical_councils /chrstuni/documents/rc_pc_chrstuni_doc_31101999_cath-luth-joint-declaration _en.html>. 
ženosti, jež má být základem jeho morální teologie, není původně biblická a teologická, nýbrž je výsledkem filosofické spekulace o cíli a o prostředcích k jeho dosažení. Není to ovšem jeho originální idea, tuto myšlenku nalezneme i u mnoha jiných autorů.

Instrumentalizace „dobrého“ skutku. Podle Vřeštála i jiných autorů nemá dobrota skutku svébytný smysl, nýbrž slouží pouze jako nástroj k dosažení jiného „dobra“, totiž vlastní blaženosti, vedle oslavy Boha. ${ }^{11}$ Jestliže však člověk jedná proto, aby skrze svůj skutek dosáhl cíle ležícího mimo tento skutek, a nikoliv proto, že tento skutek je dobrý, nabývá jeho jednání účelového, př́p. i zištného charakteru a ztrácí svou moralitu. Motivaci je třeba považovat za rozhodující: ${ }^{12}$ Koná člověk daný skutek proto, že je dobrý, nebo je mu tento skutek pouhým nástrojem k dosažení jiného cíle?

Osobní duchovní prožitky vztaženy na všechny lidi. Požadavky osobního duchovního života jsou někdy předkládány jako univerzálně zavazující mravní povinnost. Jestliže se však někomu skutečně dostane osvícení od Boha či osobního zjevení, nevyplývají z toho žádné univerzálně závazné mravní normy. Na otázku co mám dělat, kde je dobro, se často dává odpověd: Bůh sám mi zjevil, co je dobré a správné. Ukazuje mi, co mám činit. Bůh mi dává toto poznání přímo a bezprostředně. Nepotřebuji proto jiné osoby nebo instituce, abych poznal, co mám dělat. ${ }^{13}$ Lidé často jednají podle své intuice, citu, nehledají zdůvodnění správnosti svého náhledu nebo argumentují tím, že „oni to tak vidí“. Tak smýšlejí ti, kdo se dovolávají vanutí Ducha, poznání v modlitbě... a ř́kají: Vím, že to tak je, protože mi to Pán řekl. ${ }^{14}$ Toto přesvědčení může být založeno na autentickém náboženském či mystickém prožitku, ve kterém člověk přijme Boží přítomnost a lásku a bezvýhradně se vydá jí a jejímu dílu ve světě. Toto přesvědčení může být pravdivé, osobní zjevení nemůžeme vyloučit, avšak platí pouze pro svého příjemce a nevyplývají z něj univerzálně závazné mravní požadavky.

Normy církevního práva chápané jako normy mravní. Právní normy někteří autoři se samozřejmostí považují za normy mravní. Např.

11 Např. VŘEŠŤÁL. Katolická mravouka. Sv. I, s. 46: „jest tedy cílem člověka, aby plně vůli Boži, véčné blaženosti své dosáhl, a tak ke cti a slávě Boži prispival".

12 HÖFER, Josef - RAHNER, Karl (ed.). Lexikon für Theologie und Kirche. Sv. 7. Freiburg: Herder, 1962. Sloupec 616: „Christliches Ethos steht und fällt mit der Wirksamkeit seiner Motive."

13 Srov. RUF, Ambrosius Karl. Grundkurs Moraltheologie. Sv. 1. Gesetz und Norm. Freiburg im Breisgau: Herder, 1978, s. 43.

14 Viz např. Která jest cesta Páně a kterak po ní jíti čili co jest vůle Boží a jak ji plniti. Betanie: biblický časopis $k$ probouzení a pěstováni krestanského života (Tábor) 1885, s. 201-203 (bez uvedení autora). 
Miklík uvádí, že „... kanonický katalog lze nalézt v každém kapesním Kodexu (Codex Iuris Canonici, ve zkratce CIC). V něm jsou uplatněny všechny principy katolické mravovědy. On jest pro katolíka normou neodvolatelnou a také postačující. Nic v něm není vynecháno, na všechny náležité dotazy je v něm odpověd dobrá a uspokojivá.“15 Ovšem ve skutečnosti mezi morální a právní závazností je jasné rozhraničení. Je to bud' závazek konat dobro, které jako dobro poznávám, nebo požadavek disciplinovaně se podřídit určitému řádu bez ohledu na to, zda s ním souhlasím či ne. Na to, že předpisy Kodexu nenesou automaticky morální závaznost, ukazuje už i fakt, že nemají univerzální závaznost, že jsou závazné pouze „pro katolíka“.

Normy státního práva chápané jako normy mravní. Normy státního práva mnozí teologové se samozřejmostí považují za normy s mravní platností. Podle takových teologů, jako byl Řehák, Vřeštál, Jone, Schindler, jsou státní zákony zdrojem morálně teologického poznání a věřícího křestana zavazují ve svědomí. ${ }^{16}$ Jednat v rozporu se státním zákonem tedy znamená dopouštět se hříchu, což je ovšem absurdní myšlenka. To je zřejmé i ze skutečnosti, že když se změní zákony, měly by se změnit i mravní normy. Měl by se dokonce dnem, kdy změna zákona vstoupí v platnost, změnit i hlas svědomí, což by bylo $\mathrm{v}$ přímém rozporu s naukou o svědomí. Svědomí člověka by pak ztrácelo svou svébytnost a stávalo by se pouhým hlasatelem či vymahatelem právních ustanovení státu.

Teologická argumentace ve filosofické etice. Tzv. přirozená etika filosofického charakteru, jak ji najdeme i v české teologické tradici, nepřiznaně se opírající o víru se někdy zaměňuje za morální teologii či náboženskou nauku a může u nepředpojatého čtenáře vyvolávat pochybnosti o teologičnosti teologie.

Přirozená etika je filosofická disciplína pojednávající z mravního hlediska o lidském jednání, a to na základě přirozeného poznání a rozumové spekulace. Jestliže ji však vypracovává věřící křestan, může snadno upadnout do pasti metodické nedůslednosti, když do filosofické etiky zapojuje

15 MIKLÍK, Konstantin. Četba knih s hlediska morálního a kanonického. Olomouc: Matice Cyrilometodějská, 1947.

16 ŘEHÁK, Karel Lev. Katolická mravouka. Praha: Dědictví sv. Jana Nepomuckého, 1893; VŘEŠŤÁL Antonín. Katolická mravouka: doplňky a zmèny dle nové vydaného církevniho zákoniku a jiných výnosủ. Praha: Dědictví sv. Prokopa, 1919; JONE, Heribert. Katholische Moraltheologie: Unter besonderer Berücksichtigung des Codex Iuris Canonici sowie des deutschen österreichischen und schweizerischen Rechtes. 11. vyd. Paderborn: Ferdinand Schöningh, Copyright 1929; SCHINDLER, Franz M. Lehrbuch der Moraltheologie. Sv. I-III. Wien: Ambr. Opitz Nachfolger, 1907-1911. 
prvky teologie, poznatky vycházející z Božího zjevení, z církevní tradice a osobní víry. To jsou poznatky, které ve filosofii nemají místo, nebot' jsou čistě racionálně nevykazatelné. Jestliže však přesto tzv. přirozená etika takové poznatky používá, vytváří pochopitelný dojem, že ve skutečnosti není etikou filosofickou nýbrž teologickou. Protože však je ve skutečnosti filosofickou spekulací, je teologicky nekorektní. Protože však je i z filosofického hlediska nepřijatelnou, je zároveň i filosoficky nekorektní. Takto pojatá nauka tedy vrhá na teologickou etiku světlo nekorektnosti.

Jako příklad uved'me přednášku Metoděje Habáně „Mravnost“ z roku 1938. ${ }^{17}$ Jeho filosofická etika vychází z rozumového poznání a rozumové spekulace, ovšem v některých svých polohách se skrytě a nepřiznaně opírá o Boží zjevení a křestanskou víru, nebot bez ní by k mnoha závěrům vůbec nebyla schopna dojít.

Protože se v Habáňově filosofickém textu náhle objevují teologické argumenty, vytváří se tím dojem, že toto je teologie. Zároveň je ovšem zřejmé, že takováto teologická etika ve skutečnosti teologií není a podezření, že ve skutečnosti není teologií, může padat na celou morální teologii.

Nereflektování historicko-společenské a kulturní podmíněnosti. Teologové logicky vždy mají nějaký náhled na historické, společenské a kulturní podmínky, je však otázkou, do jaké míry si jsou vědomi, že to je jejich vlastní politický náhled na proměnný stav a proměnné události ve společnosti. Teologie by měla stav společnosti reflektovat, avšak měla by na něm být pokud možno nezávislá.

Teologický charakter teologické etiky je zpochybňován skutečností, že je závislá na proměnných událostech ve společnosti, i když třeba sama o sobě tvrdí, že na nich závislá není a že čerpá z nadčasového a naddějinného Božího zjevení. Např. pokud jde o vztah křestana ke státu, musíme konstatovat znatelný rozdíl mezi situací, kdy České země byly součás-

17 HABÁŇ, Metoděj. Mravnost. In Dobrá cesta: výbor z prednášek IX. prázdninového kursu katolického učitelstva československého v Domažlicich 1938. Olomouc: Krystal, 1938, s. 80-83. Poslední věta této filosofické přednášky (s. 83) zní: „V jednotlivém případě jednání dává pravidlo lidský rozum, co je správné a co je nesprávné, jehož schopnost soudit správně pochází z Věčné Moudrosti Boží, podle níž byl člověk stvořen." Závěr této věty je ovšem výpověd" teologická. - Podobně postupuje i KADEŘÁVEK, Eugen. Jak soudi zdravý rozum o mravnosti náboženské a bezbožecké. Praha: nákladem spisovatele, 1902, s. 30-31. Po obsáhlém filosofickém výkladu naprosto neorganicky formuluje výzvy: „Osvojme si tedy mravnost náboženskou.“ „Osvojme si tedy mravnost křestanskou.“ Posléze činí závěr, že „pravou mravnost náboženskou hlásá nám jediná církev katolická“. Aniž bychom se vyjadřovali k pravdivosti těchto vět, musíme konstatovat, že jde o výpovědi teologického charakteru, pro které nejsou ve filosofickém pojednání vytvořeny předpoklady. 
tí Rakouska-Uherska, a situací samostatného Československa. Výrazným zájmem českých morálních teologů za Rakouska byl důraz na to, že proti vládě, dokonce i proti nelegitimní, nikdy není dovoleno vyvolat revoluční povstání, nebot' její moc je od Boha. Jak se vládce k moci dostal, je odlišná otázka, která neruší závazek poslušnosti. ${ }^{18}$ Naproti tomu v morálně teologické literatuře ze čtyřicátých let dvacátého století je toto téma zcela pominuto. ${ }^{19}$ Teologové ovšem $\mathrm{v}$ letech těsně po druhé světové válce nemohli tušit, jak aktuální se tato otázka stane o rok či dva později. Z toho důvodu pak jejich teologie pro křestany v době komunistické vlády neposkytovala v této věci dostačující orientaci.

Partikularizace univerzálně platných mravních norem. Teologická etika se opírá o křestanskou antropologii a její požadavky platí s univerzální závazností. To ovšem někteří teologové nepřijímali a výslovně promlouvali ne ani obecně k lidem věřícím v Boha, ne ani ke křestanům vůbec, nýbrž pouze ke katolickým křestanům, ${ }^{20}$ a to i přes skutečnost, že univerzalita křestanského poselství spásy je nepopiratelná. Podle některých teologů tedy zřejmě byla katolická morální teologie vnitřní katolickou „spolkovou“ záležitostí, která se nekatolíků přímo netýká a k ničemu je nezavazuje.

Kdyby ovšem morální teologie neměla na mysli každého člověka a kdyby se se svým poukazem na mravní zákon neobracela ke všem lidem, představovala by pouhý partikulární zájem, což by zpětně ukazovalo, že nestaví na univerzálním Božím zjevení určeném pro každého člověka. ${ }^{21}$

18 STÁREK, Jan. Katolická mravovéda. Praha: Dědictví sv. Prokopa, 1884, s. 57-58.

19 DACÍK, Reginald M. Mravouka. Olomouc: Dominikánská edice Krystal, 1946; PECKA, Dominik. Umèni žiti: katolická mravouka. Praha: Vyšehrad, 1947.

20 Např. AUGUSTIN, Bedřich. Mravouka. Praha: Českoslovanská akciová tiskárna, 1926, s. 3: „Katolická mravouka jest věda o mravním jednání člověka podle Bohem stanoveného mravního řádu.“ AUGUSTIN, Bedřich. Mravouka pro III. tř́du střednich škol. Praha: Vyšehrad, 1946, s. 5: „Katolická mravouka ukazuje, jak máme podle vủle Boží žíti, abychom byli dobří a dosáhli věčného spasení.“ Tyto výroky jsou zřejmě míněny tak, že jiná než katolická mravouka Bohem stanovený mravní řád neukazuje a neukazuje cestu, jak máme žít, abychom byli dobří a dosáhli věčného spasení.

21 Pokud bychom přijali toto přesvědčení o partikularitě křestanského poselství, znamenalo by to, že bychom se ztotožnili s postmoderní rezignací na celkový a celistvý náhled na svět a na člověka a že bychom přijímali rozpad světa na jednotlivé oblasti poznání a pravdy, nad nimiž žádný celkový náhled není možný. Křestanský univerzální nárok a misijní poslání ke všem lidem by tak byly opuštěny. Nicméně je nutno konstatovat, že v první polovině 20 . století, ještě před postmoderním rozpadem světa, nebyla římskokatolická církev takovým způsobem otevřená vůči křestanům jiných vyznání, vůči nekřestanům věřícím v Boha či vủbec vůči všem lidem, u nichž je cokoli dobrého a pravdivého, co může být považováno za přípravu na evangelium ( $\mathrm{Lu}$ men Gentium, čl. 16), jak to považujeme za samozřejmé po II. vatikánském koncilu. 
Na jednu stranu se všem lidem předkládala povinnost věřit v Boha. Na druhou stranu adresují někteří moralisté svou nauku ne všem lidem, nýbrž jen katolickým křestanům, zřejmě proto, že nemají dostatečné argumenty, aby ji před jinými lidmi obhájili. Řešením některých je, že všichni lidé mají povinnost věřit $\mathrm{v}$ Boha a každý člověk žijící podle přirozeného zákona dostane někdy v životě milost, aby mohl uvěřit. Pokud jí nevyužije, je to jeho vina a bude za to oprávněně potrestán.

Tohoto rozporu a této teologické nedostatečnosti si ale tito teologové zřejmě nejsou vědomi. Pohybují se ve svém jasně uspořádaném, ale uzavřeném myšlenkovém světě, ve kterém na některé otázky není odpovědi, resp. takové otázky jsou zakázány. Nahlížejí na Boha prizmatem našich lidských idejí a schémat a jim jeho obraz podřizují - např. že Bůh musí hříšníky potrestat, jinak by nebyl spravedlivý.

Nerozlišení závaznosti mravních a náboženských norem jednání. Čeští morální teologové dřívějších dob často připisovali náboženským normám jednání mravní, tedy univerzálně zavazující platnost. ${ }^{22}$ Náboženské normy ovšem zavazují pouze příslušníky daného náboženství či konfese na základě jejich víry. Evidentně nemají univerzální platnost, jejich partikularita je pak ovšem neoprávněně přenášena i na normy mravní, které jsou pak také vykládány jako normy s partikulární platností. Z toho plyne přesvědčení, že katolickou církví vyhlašované mravní normy platí pouze pro katolíky. ${ }^{23}$ Pro všechny platné

22

Doklady této záměny lze běžně najít v mravních příručkách, katechismech apod.

Např. KOCH, G., upravil OLIVA, Arnošt. Mravouka podle katechismu v krátkých promluvách. Praha: Kropáč \& Kucharský, 1937, s. 29 uvádí, že největšího hříchu se dopouští ten, kdo vůbec nevěří v Boha: „Víra jest nutná, bez víry nemůžeme se Bohu líbiti. [...] Proč jest nevěra největší ze všech hříchů?“ Že má autor na mysli víru předkládanou katolickou církví, je zřejmé ze slov na str. 30: „Odpadnout od pravé víry znamená vystoupiti z Církve a státi se na př. vyznavačem některé sekty nebo zůstati bez vyznání. Kde se jedná o víru, musíme vždy mysliti na tu víru a míti tu víru, již dal Kristus své Církvi. Církev od dob apoštolských učí, že jest sedm svátostí, kdo to popírá, nemá celé víry Kristovy. [...] Zř́íkáme-li se pravé katolické víry, bereme perlu z ruky Kristovy a zahazujeme ji do bláta." Z Kochových slov musíme učinit závěr, že kdyby někdo žil podle sebeušlechtilejších etických zásad, ale nevěřil v Boha, stejně by se Bohu nelíbil a všechno jeho životní úsilí by bylo před Bohem zbytečné. Mravní požadavky má tedy smysl předkládat pouze člověku věřícímu, jen on může být před Bohem mravným člověkem. Autor knihy svá slova zřejmě adresuje pouze věřícím katolíkům, i když to nikde neuvádí. Na druhou stranu ovšem byli i teologové, kteří univerzalitu mravního požadavku naprosto pregnantně formulovali, např. ZAVORAL, Method. Kristus a cirkev: apologetické promluvy. Praha: Cyrillo-Methodějské knihkupectví Gustav Francl v Praze, imprimatur 1913, s. 203: „Mravní zákon katolické církve je jasný a určitý [...] Zákon, ten musí proto býti žulově pevný, aby se o něj malomocně tříśtily útoky sebe zuřivější; musí být nezměnitelný a stejný pro všechna srdce, pro všechny věky, pro všechna místa.“ 
mravní normy, jako např. nerozlučnost manželství, jsou vnímány jako katolické specifikum, které zavazuje pouze katolíky.

Partikulární, neuniverzální náboženské normy jednání ovšem mohou vytvářet závaznost, jejíž porušení může být pro př́íslušníka daného náboženství hříchem. Katolík se tedy může dopustit hříchu, i když neučiní nic mravně špatného, tedy neporuší mravní normu, avšak poruší normu náboženskou. Z lenosti se nezúčastnit v neděli slavení eucharistie je pro katolíka hřích, i když to není porušení povinnosti platné pro všechny lidi. Tato partikulární náboženská norma jednání je zdůvodněna nábožensky.

Nerozlišení mravní a morální roviny jednání. Boží zjevení s sebou nese i mravní nárok, nárok na to, jak člověk má jednat. Je to i zvěst o tom, co je dobro a co je zlo. Pro jedince, který se rozhoduje a jedná, je rozdíl mezi dobrem a zlem v morálním smyslu primárně dán tím, o čem on je vnitřně opravdově přesvědčen, tedy hlasem jeho svědomí. To je primární, autonomní rovina etického hodnocení.

Moralita a mravnost představují dva komplementární náhledy na lidský čin. Moralita znamená náhled z nitra člověka, z jeho vlastního poznání. Mravnost je náhled zvnějšku, z hlediska mravních norem a mravního zákona. Povinností lidského subjektu je, aby usiloval o náhled v maximální míře transsubjektivní, aby správně poznával obecně přijaté mravní normy, požadavky lidského i Božího zákona, aby reflektoval mravní zkušenost církve i společnosti. Toto jeho mravní poznání však vždy bude poznáním jeho jako subjektu a hranici mezi svým poznáním mravnosti a „objektivně platným“ mravním zákonem nikdy nemůže překročit, objektivity mravnosti se nikdy nemůže zcela dobrat. Moralita je osobní náhled na to, co je mravní závazek v dané situaci. Podle přesvědčení určitého člověka by bylo povinností každého člověka ve stejné situaci jednat tak, jak se rozhoduje on. Ale je to jen jeho vlastní náhled, který jiní lidé nemusejí nutně sdílet, i když třeba pro něj samotného platí jako nejvyšší závazek. Člověk má ovšem morálni povinnost usilovat o mravní dobro, tedy o respektování požadavků vnějších, heteronomních mravních norem, i když jsou proti moralitě až druhotné.

Jestliže se tyto dvě roviny zamění, redukuje se moralita člověka na poslušnost vủči mravním normám, a to bez ohledu na to, zda jejich aplikaci na danou situaci rozumí či ne či zda ji považuje za náležitou či ne. Pro takovou záměnu či pro takové nerozlišení lze uvést veliké množství př́íkladů, nebot’ „předkoncilni“ morálka se do velké míry formulovala jako morálka poslušnosti. ${ }^{24}$

24 Např. AUGUSTIN, Bedřich. Mravouka pro III. třídu střednich škol, s. 10: „Opravdovou cenu před Bohem i před lidmi má jen ten, kdo plní svědomitě všechny po- 
Jakmile se ovšem poslušnost vủči vnější autoritě stane slepou, ztrácí svůj teologický a náboženský charakter a stává se heteronomní poslušností strachu ze sankce či žádostivosti po zisku a prospěchu.

Pro křestana mravní život a moralita a spiritualita často splývají v jedno kontinuum a pro daného jednotlivce by bylo třeba vážnou zradou a nevěrností Bohu, kdyby např. nevstoupil do kláštera, když jasně poznává, že to je povolání a úkol od Boha mu daný. Jestliže ovšem požadavek své vlastní spirituality předkládá jako mravní povinnost pro všechny, což nemůže být oprávněné, zpochybňuje tím platnost morálně teologické argumentace.

To jsou problémy, které z pohledu současné morální teologie vidíme v dřivějších teologických postojích a ve způsobu teologické argumentace a kterých je třeba se varovat, má-li teologie být schopna oslovit samostatně kriticky smýšlejícího člověka. Tím se samozřejmě neodmítá pastorační ohled na člověka, kterému kritická teologická reflexe není vlastní.

\section{Teologická teologická etika v době staré i nové}

Jasné potvrzení teologického charakteru teologické etiky nacházíme, na rozdíl od mnohých českých moralistů, u mnoha jiných teologů v době starší i novější.

Tomáš Akvinský měl rozhodující význam pro formování morální teologie ve středověku. Pro naši otázku je důležité, že i druhá část jeho Sumy, která se zabývá morálními otázkami, má teologický charakter v neomezeném smyslu a neobsahuje pouze praktické pokyny pro křestanský život, jak tomu bylo u některých jiných autorů. ${ }^{25}$ Podle Tomáše Bůh je alfa a omega, princip a cíl dějin spásy a křestanského života. Protože člověk je obrazem Božím, Tomáš chápe člověka a smysl jeho skutků skrze Boha, v Bohu a morální teologie má pro něj plně „božský“ charakter. Tímto způsobem se Tomášovi podařilo propojit spekulativní a praktickou část morální teologie a zajistit její homogenní teologický charakter.

vinnosti.“ Jan Stárek v Katolické mravovědě uvádí jako vrchol ctnosti poslušnosti poslušnost slepou. Jestliže ji máme, ne jen vykonáme, co nám nadřízený přikazuje, ne jen se i vnitřně ztotožníme se jeho vůlí a chceme to, co chce on, nýbrž dokonce „i s úsudkem v obět přineseným vrchního posloucháme a tak beze zkoumání též smýšlíme, co on smýšlí“ (s. 58). S touto slepou poslušností máme přijímat vůli Boží i vůli neomylného učitelského úřadu církve a je též chvályhodné, záslužné a vlastně nutné, abychom takto přijímali i rozkazy jiných vrchností. Po zkušenostech s totalitními režimy ovšem musíme my říci, že přijmout vůli i smýšlení druhého člověka „beze zkoumáni““ není ctností, nýbrž zavrženíhodnou neřestí.

25 Např. Alanus ab Insulis. Viz HOFMANN, Rudolf. Moraltheologische Erkenntnis- und Methodenlehre. München: Max Hueber Verlag, 1963, s. 26. 
Tomáš se stal příkladem pro další bádání v morální teologii a stojí zároveň v kontrastu s dřívějším i pozdějším kasuistickým způsobem morálně teologického myšlení, které se do značné míry soustředilo na praktické otázky ve smyslu problémů svědomí (pro potřeby zpovědní praxe) a nesnažilo se o hlubší teologické chápání. Jestliže penitenciály konkrétně stanovovaly pokání za určité hříchy, ani neměly snahu hledat pro to teologické zdůvodnění a byly spíše něčím jako trestním sazebníkem. ${ }^{26}$ Prokazatelně nestavěly na Božím zjevení nýbrž na lidské spekulaci a společenské praxi.

Jako př́klad z novodobé historie „teologické“ teologické etiky uved'me fundamentální morální teologii Franze Böckleho. ${ }^{27}$ Lze bez omezení tvrdit, že jeho etika má přísně teologický charakter, ne ovšem proto, že by opakovala či vykládala biblické mravní normy, nýbrž proto, že klade otázku, kde je spojnice mezi racionální autonomní etikou a náboženskou vírou. Zdánlivě se dostávají do rozporu, nebot náboženská morálka se zdá být nevyhnutelně heteronomní, Bohem člověku uložená a nařízená. Jejich zdánlivý rozpor však Böckle řeší určitou koncepcí křestanské antropologie a je zcela vyloučen pojmem „theonomní autonomie“.

Křestanská antropologie je styčným bodem mezi autonomní morálkou a náboženskou vírou. Mravní normy nejsou heteronomně zdůvodňovány tajemstvím víry, nýbrž tím, že na základě víry víme, jaký je člověk. Křestanská antropologie umožňuje pochopení, že i náboženská víra a náboženská morálka může být srozumitelná a přijatelná pro člověka moderní evropské kultury usilujícího o mravní autonomii. Opěrnými pilí̌ri takové z křestanské víry vyrůstající antropologie jsou tři skutečnosti: Člověk je

1. stvořený Bohem (a povolaný k věčnému životu),

2. vykoupený Kristem (v něm nám Bůh nabízí spásu),

3. povolaný realizovat plnost možností lidské přirozenosti (oslovovaný Bohem, který mu ukládá poslání).

Skrze náboženskou antropologii víra ovlivňuje hierarchické seřazení hodnotových statků a mravních hodnot. ${ }^{28}$ Takovou hierarchii nutně má na základě svého poznání a své zkušenosti každý člověk, věřící křestan pak má hierarchii ovlivněnou náboženskou antropologií. Tím hraje víra významnou roli v uskutečnění morálně relevantního náhledu a zdůvod-

26 Srov. VAŠICA, Josef. Literárni památky epochy velkomoravské 863-885. Praha: Lidová demokracie, 1966.

27 BÖCKLE, Franz. Fundamentalmoral. Leipzig: St. Benno-Verlag, 1981.

28 BÖCKLE. Fundamentalmoral, s. 192. 
nění mravních norem. Mravní autonomie jednotlivce, každého člověka i věřícího křestana, při tom zůstává nenarušená a dovršuje se jako autonomie theonomní, Bohem uložená. ${ }^{29}$

Morální teologie je stř́zizlivá racionální nauka o věcech, které přesahují racionálno nebo jinak řečeno jdou částečně mimo racionalitu, nebot náboženská víra, o kterou se teologie opírá, není jen racionální. Je to zásadní životní rozhodnutí, osobní setkání se zjevujícím se Bohem, vidoucí a zároveň slepý krok měnící život a na životní zkušenosti závislý.

Teologická etika hledá odpovědi na otázku, kterou si člověk opakovaně klade, totiž co mám dělat, jak mám jednat, kde je dobro a spravedlnost. Odpověd' lze hledat i způsobem neteologickým, jak to ostatně zhusta je. Teologická etika musí při svém racionálním zkoumání vycházet z Božího zjevení, tedy z Písma a jeho mravního poselství. Jenže to je zahaleno do šatu starého mnoho staletí a přes tuto proluku $\mathbf{v}$ čase a přes rozdílnost kultur, společenské situace, historické zkušenosti atd. je těžko přímo přenášet konkrétní mravní pokyny Bible do naší doby. Takže se nakonec zdá, že z biblických mravních směrnic kromě nejobecnějších principů pro naši nynější situaci př́mo čerpat nemůžeme a musíme se spolehnout na naše vlastní hledání mravního dobra. Opustit zdroj Božího zjevení a nahradit jej pouhou lidskou zkušeností a lidskou spekulací by ovšem znamenalo opustit teologii, nebot' „teologie je vědecké poznání a nauka o sebeodkrytí Boha, jež se uskutečňuje ve zjevení. ${ }^{30}$ Pokud chceme v teologii zůstat, nesmíme opustit hledání z teologických zdrojů, tedy z Božího zjevení, ke kterým se samozřejmě připojuje i lidská moudrost a racionální reflexe. Boží zjevení nám neříká přímo, co máme činit v jednotlivých konkrétních situacích svého života, avšak poskytuje nám směrnici a ukazuje nám cesty, jak máme na tuto otázku hledat odpověd'.

Jestliže morální teologie čerpá z Božího zjevení principy křestanské antropologie, stojí pevně na jeho základech. Naproti tomu odvolávat se př́mo na Boží vůli jako zdroj konkrétních norem pro naše jednání může

29 BÖCKLE. Fundamentalmoral, s. 57-66. BÖCKLE, Franz. Theonome Autonomie: Zur Aufgabenstellung einer fundamentalen Moraltheologie. In HÜBNER, Siegfried (ed.). Theologisches Jahrbuch 1974. Leipzig: St. Benno-Verlag, 1974, s. 274-299.

30

HOFMANN, Rudolf. Moraltheologische Erkenntnis- und Methodenlehre, s. 101: „Theologie ist wissenschaftliche Erkenntnis und Lehre über die in der Offenbarung erfolgende Selbsterschließung Gottes. Sie hat zum Gegenstand das Sein und Wirken Gottes, dessen Mitteilung der Christ im Glauben empfängt. Auch da, wo sie sich, wie das in der Moraltheologie sehr weitgehend der Fall ist, dem Menschlichen und Geschöpflichen zuwendet, ist dieses Kreatürliche nicht als solches ihr Gegenstand, sondern nur insofern es von Gottes Offenbarung betroffen ist und folglich in einer dadurch geschaffenen Beziehung zu Gottes Heilswirken steht.“ 
sice být výrazem zbožnosti a náboženského povznesení nebo nároku na jakési nadpozemské poznání, avšak je v rozporu s principy teologické etiky. ${ }^{31}$ Autonomie pozemského bytí znamená, že člověk to, jak se má konkrétně rozhodnout, musí hledat sám, Bůh mu mravní pokyny nediktuje, nýbrž mu právě ukládá, aby odpovědi hledal ve své svobodě a autonomii. Teologická etika čerpá i z Božího zjevení, avšak je to nauka lidská, nikoliv Boží. Představa, že Bůh nám přímo říká, co máme činit v jednotlivých situacích, je falešná.

\section{Překážky}

Tomuto racionálnímu teologickému postupu se staví do cesty některé překážky. Uved'me nejčastější:

1. Všechny právní či disciplinární kroky, které by omezovaly svobodnou teologickou práci a bádání a nebyly zdůvodněny teologicky, tedy obhajitelně z hlediska Božího zjevení i racionální reflexe.

2. Náboženská manipulace $s$ cílem držet lidi v poslušnosti, přimět je volit určitou politickou stranu, dát peníze na určitý účel... Teologie a její racionální argumentace bývá v takových situacích vyloučena jako nežádoucí.

3. Př́má argumentace Boží vủlí. Výroky jako: „Toto je dobré, to konej, protože to nám nařizuje Bůh" předstírají, že můžeme s Bohem bezprostředně komunikovat a že on nám lidem sděluje své univerzálně zavazující normy jednání. Ve skutečnosti však nemůžeme s Bohem přímo mluvit, aby nám řekl, co je jeho vůle. Máme jen to, jak my chápeme jeho zjevení a jak toto své pochopení formulujeme.

4. Nebezpečí slepé poslušnosti. Jde o nepochopení nauky I. vatikánského koncilu o neomylnosti papeže ${ }^{32}$ a rozširření této neomylnosti na jakoukoliv církevní nauku, bez rozlišení nauky víry a vyvíjející a měnící se nauky o mravech. ${ }^{33}$ Na nebezpečí slepé poslušnosti a disciplíny poukazuje např. Bernhard Häring v úvodu ke své knize Frei in Christus. Pou-

31 Viz výše nerozlišení požadavků osobního duchovního života a požadavků univerzálně zavazující mravnosti. Citovaný anonymně publikovaný článek Která jest cesta Páně a kterak po ní jíti čili co jest vůle Boží a jak ji plniti, s. 201-203, argumentuje bezprostředním náhledem do Boží vůle. Podobný smysl má zdůvodnění nějakého mravního požadavku slovy „Bůh to tak chce“ nebo „Bůh to nenávidí“ nebo „Bủh mi nařídil...", s nímž se můžeme setkat v různých zbožných textech či promluvách. Taková formulace je výrazem osobní zbožnosti, ne však výrokem teologickým.

DS 3074.

3 Např. KOCH, G., upravil OLIVA, Arnošt. Mravouka podle katechismu v krátkých promluvách, s. 29: „Kristus ví všecko a své Církvi všecko řekl, proto máme všecko bez výjimky za pravdu, co nám Kristus a Církev praví.“ 
kazuje na hrůzné zážitky poslušnosti, v tomto př́padě poslušnosti vůči nemilosrdnému politickému systému Hitlerovu, které Häringa dovedly k jasnému přesvědčení, že jednostranné zdůrazňování poslušnosti ji zbavuje jejího křestanského smyslu a činí ji nebezpečnou. ${ }^{34}$ Základním požadavkem evangelia přece není poslušnost a církevní disciplína, nýbrž přijetí osvobození od Boha a život ve svobodě a tvořivosti a ve věrnosti Bohu a církvi. Proto může Häring napsat: „Proto trpím s církví, když vidím, že její části jsou ještě v zajetí tradicí, které stojí zcela a jasně v protikladu k osvobozující síle víry a naděje, k všeobjímající lásce, ke které nás Bůh volá.“35 Tento Häringův postoj nebyl kritikou církevních poměrů či církevní vnitřní i vnější politiky, nýbrž upřímným výrazem jeho utrpení z nepravostí v církvi a jeho snahy o nápravu. ${ }^{36}$

O slepé poslušnosti jako vrcholu ctnosti poslušnosti pojednává např. Jan Nep. Stárek roku 1884. Nejvyšším stupněm ctnosti poslušnosti je podle něj poslušnost slepá, ve které ne jen vykonáme, co nám nadřízený přikazuje, ne jen se i vnitřně se jeho vưlí ztotožníme a chceme to, co chce on, nýbrž „i s úsudkem v obět přineseným vrchního posloucháme a tak beze zkoumání též smýšlíme, co on smýšlí“. ${ }^{37} \mathrm{~S}$ touto slepou

34 HÄRING, Bernhard. Frei in Christus. Sv. I. Freiburg: Herder, 1979/1989, s. 18: „Die erschreckenden Erlebnisse des Gehorsams gegenüber dem herzlosen System Hitlers riefen meinen kritischen Sinn wach, und so kam ich zur klaren Überzeugung, daß eine einseitige Betonung des Gehorsams ihn seines christlichen Sinnes entleert und gefährlich macht. Im Sanitätsdienst der Deutschen Wehrmacht, an der russischen Front vom ersten bis zum letzten Tag des Krieges, zeigte sich mir die Heilssorge der Kirche in neuer Sicht. Wir müssen uns neuen Problemen mutig stellen und uns von vielen unechten Fragen und Antworten lösen.“

Tamtéž, s. 19: „Darum leide ich mit der Kirche, wenn ich sehe, daß Teile derselben noch Gefangene der Traditionen sind, die ganz und gar im Widerspruch stehen zu der befreienden Kraft des Glaubens und der Hoffnung, zu der allumfassenden Liebe, zu der Gott uns beruft.“ Překlad L. O.

36 K morálce poslušnosti viz též např̀. Velký katechismus katolického náboženství: církevně schváleno ... 17. ledna 1946... Praha: Státní nakladatelství, 1947, s. 7, otázka. 24: „Kdy jest víra naše obecná? - Víra naše jest obecná, věříme-li všecko bez výjimky, čemu církev katolická učí.“ Neupřesňuje se ovšem, zda se to týká jen nauky neomylné, je to zevšeobecněno na všechnu nauku. A taková víra je podle katechismu podmínkou spásy - otázka 22 tamtéž říká: „Víry jest k spasení nevyhnutelně třeba..." STÁREK, Jan Nep. Katolická mravovéda, s. 348. „Třetího stupně dostoupá poslušnost, když netoliko vyplněním díla a s poníženou vủlí, alebrž i s úsudkem v obět přineseným vrchního posloucháme a tak beze zkoumání též smýšlíme, co on smýšlí, leč by patrně hříšný byl příkaz jeho. Totě ono dokonalé, jinak slepým nazývané poslušenství, o němž chvalně připomínají svatí Otcové; jelikož tím člověk úplně sebe sama zapírá a obětuje Bohu jako obět zápalnou. Tohoto poslušenství Bohu, toho církvi v učitelském úřadu neomylné prokazovati máme. Jiným vrchnostem tutéž poslušnost prokazovati chvalno a záslužno jest, ano na jistý způsob také nutno, pokudž hnutí vůle nemálo závisí na úsudku rozumu, ježto by sotva kdo, jak nutno k rozkazu vrchního s podrobenou vůlí stál, jestliže by úsudek svůj k úsudku vrchního nepřivětil.“ 
poslušností máme podle Stárka přijímat vůli Boží i vůli neomylného církevního magisteria a je též chvályhodné, záslužné a vlastně nutné, abychom takto přijímali i rozkazy jiných vrchností.

5. Přesvědčení, že bud'to mravní požadavky teologické etiky mají absolutní nadčasovou platnost a nepodléhají vývoji, anebo že se sice ve svých dřívějších nedokonalých stádiích teologická etika vyvíjela, ale $\mathrm{v}$ této chvíli dospěla $\mathrm{v}$ našem poznání $\mathrm{k}$ plnosti a $\mathrm{v}$ budoucnosti se proto dál vyvíjet a měnit nemůže a nebude. Toto by však bylo popřením dynamického vývojového charakteru morální teologie, která z podstaty věci se musí zabývat stále novými problémy a otázkami, které přináší běžící život, i novými poznatky věd o člověku a společnosti i novými poznatky o církvi a jejím životě. Příkladem může být postoj k mučení člověka. Papež Inocenc IV. ve své bule proti čarodějnictví r. 1252 nařídil mučení, podle Pia XII. mučení je vždy a podstatně v rozporu s přirozeným mravním zákonem. Jeho zákaz můžeme tedy označit za absolutně zavazující mravní normu. ${ }^{38}$ Plyne z toho však, že tato námi přijímaná mravní norma, která se $\mathbf{v}$ minulosti tak radikálně proměnila, bude i v budoucnu platit stejným způsobem, jak ji hlásáme dnes, bez ohledu na okolnosti, které mohou být velmi změněné? To nelze s jistotou tvrdit, tak jako to nelze tvrdit o jiných mravních normách.

\section{Morální a dogmatická teologie}

Teologie je rozdělena do několika oborů, z nichž jedním je teologie morální. Je důležité ujasnit, co má společného s dogmatickou teologií a jak se liší.

Morální a dogmatická teologie mají stejný materiální předmět. Je významné, že morální teologie je do stejné míry zaměřena na Boha resp. na Boží zjevení jako dogmatika, že obě hledají hlubší porozumění obsahu křestanské víry. Obě slouží víře a umožňují věřícím lépe jí rozumět a v důsledku toho ji lépe prožívat a uplatňovat v životě.

Rozdíl obou disciplín je v jejich formálních předmětech, v jejich specifickém hledisku. Morální teologie má normativní charakter, hledá normy, podle kterých má člověk jednat, aby jednal dobře. Morální teologie zkoumá jiný aspekt reality, v níž stojí Bůh a člověk, než dogmatika, je jinou výpovědí o člověku a o Božím zjevení. Je to aspekt mravní a morální, který zprostředkovaně přes křestanskou antropologii a pojetí mravních hodnot ukládá úkol realizace, tedy úkol určitého jednání. Nemluví jen o tom, co

38 HÄRING, Bernhard. Frei in Christus. Sv. I, s. 356. 
jest, nýbrž i to tom, co být má. Nemluví prostě o existujících skutečnostech, nýbrž o nároku kladeném na člověka, o tom, jak člověk má jednat. Toto jednání, které je uloženo, je jednání ve svobodě a zodpovědnosti. Je to uložené jednání, pokud jde o jeho formu - má vždycky odpovídat požadavkům morality, hlasu svědomí, a pokud je to možné i požadavkům mravnosti, mravních norem. Pokud jde o materii, konkrétní obsah požadavku mravnosti, nelze v této obecnosti nic bližšího vypovědět. Tím se zabývá speciální morální teologie.

Teologická etika se zabývá obsahem víry, pokud se dotýká osobní zodpovědnosti člověka za svobodné lidské skutky, za rozhodnutí učiněná před Bohem - před tváří Boží i tohoto světa. Mravní rozhodnutí vždy přináleží člověku jakožto mravnímu subjektu. Tuto osobní zodpovědnost nelze popřít a jakoby přenést na Boha poukazem na jeho vůli, na jeho stvořitelský záměr, na jeho přirozený zákon apod. ${ }^{39}$ Tím méně ji lze přenést na autoritu lidskou jakéhokoliv druhu a stupně. O vlastních skutcích se rozhoduje daný člověk sám, ne za něj Bůh či jiná autorita.

Tak přispívá morální teologie prostřednictvím „vědeckého“ poznání k proniknutí do opravdové podoby a bohatství lidského a křestanského života. ${ }^{40}$ Zkoumá význam víry pro život. Jde v ní o vztah víry $v$ Boha a mravnosti, ne př́mo o vztah Boha a mravnosti, nebot zdrojem poznání pro teologii není př́mo Bůh, on není předmětem jejího zkoumání, nýbrž víra v Boha. Bůh jako takový stojí mimo hranice možností lidského zkoumání, to si za svůj předmět v tomto případě bere víru v Boha a formulace této víry ve vyznání víry.

Teologická etika slouží k růstu křestanského náhledu na to, jak má jednat člověk, všichni lidé, bez ohledu na to, zda jsou věřící nebo nevěřící. Zároveň ale slouží křestanům k růstu víry a života podle víry, růstu svobody v Kristu a věrnosti Kristu, usiluje o pravé vidění božské a lidské skutečnosti.

39 Nauka o skutcích, jež jsou intrinsece malum, by v této souvislosti vyžadovala dalšího vysvětlení.

40 Srov. HOFMANN, Rudolf. Moraltheologische Erkenntnis- und Methodenlehre, s. 66 : „Die Moraltheologie dient in erster Linie dem Glauben selbst, seinen selbstverständlichen Bedürfnissen nach Weitung und Vertiefung der Glaubenseinsicht. In dieser Bestimmung steht sie als Teil der systematischen Theologie voll und ganz neben der Dogmatik. Der Unterschied liegt in dem besonderen Gesichtspunkt. Sie betrachtet den Glaubensinhalt, insofern er in irgendeiner Hinsicht die persönliche Verantwortung des freien menschlichen Tuns anspricht. Ihr Bemühen geht auf eine höhere Einsicht, die man vielleicht als gläubig-sittliche Werteinsicht bezeichnen kann. So leistet sie mit den Mitteln wissenschaftlicher Erkenntnis den theologischen Beitrag für ein höheres Verständnis des Reichtums des christlichen Lebens, der Vielheit seiner Möglichkeiten. Ihr ist eine eindringliche Erkenntnis der Echtheit, der Lebensgültigkeit und Lebensbedeutung des Glaubensinhalts aufgegeben.“ 
Morální teologie se snaží najít a formulovat, co víra vyžaduje od člověkovy vůle, normativní význam víry, její složku požadující realizaci. Není to požadavek přímo na jednání, to může být nesvobodné, ale vůle je svobodná. Násilník může přinutit druhého člověka, aby dělal, co nechce, ale nikdo jej nepřinutí chtít, co nechce.

\section{Mravní zodpovědnost jednotlivce}

Úkol morální teologie není omezen jen na vytvoření systému norem mravního jednání, co možná nejkonkrétnějších a co nejpříměji aplikovatelných. Morální teologie nemůže nahradit úlohu svědomí a „osvobodit“ člověka od jeho mravní zodpovědnosti, od jeho vědomé věrnosti Kristu. Subjektem a nositelem zodpovědnosti je vždy konkrétní člověk a jeho individuální zodpovědnost nemůže nikdo a nic převzít

Morální teologie nedává př́mé, bezprostřední, konkrétní návody k jednání, každý se ve smyslu morality musí rozhodovat sám. Zodpovědnost za rozhodnutí nelze přenést na autoritu nad člověkem stojící. Morální teologie takovou autoritou není, nesupluje rozhodnutí svědomí v jednotlivých situacích, nebere svobodu rozhodování, nediktuje určité jednání.

Kdyby se morální teologie chápala jen jako systém mravních norem, zanedbávala by náboženský charakter křestanské morálky a tím by protiřečila duchu Písma, pro které mravnost, morálka je neoddělitelná od náboženství, od vztahu k Bohu. „Radostná zvěst“ Písma hlásá mocné skutky Boží pro jeho lid, což vytváří novou realitu. Požadavky určitého způsobu jednání a života, které Bůh staví, jsou až druhotné, jsou možné a smysluplné pouze na pozadí této nové reality. Boží imperativ je předcházen Božím indikativem. ${ }^{41}$

\section{Závěr}

Tímto pojetím teologičnosti morální teologie se dostáváme do bodu zlomu a je nadmíru důležité, jakým směrem půjdeme dál, do jaké míry noví nositelé teologického myšlení budou myslet skutečně teologicky. I přes od-

41 Srov. HÄRING, Bernhard. Láska je víc než prikázání. Praha: Česká katolická charita, s. 41-42: „Již v Desateru je před přikázáním radostné poselství. ,Já jsem Hospodin, tvůj Bůh, který tě vysvobodil z Egyptské země a z domu poroby“ (Ex 20,2; Dt 5,6). Z toho vyplývá, že Bůh má na podkladě nového titulu právo na to, aby mu Izrael věnoval celou svou lásku a věrnost a neměl žádné jiné bohy, kromě jednoho pravého Boha Úmluvy (Dt 5,7). Protože mu Bůh prokázal takové divy své lásky, musí chápat, že jeho lásku je třeba brát vážně. Bůh bere svůj lid naprosto vážně; proto také je tak vážné přikázání lásky. ,Já, Hospodin, jsem Bůh žárlivý‘ (Dt 5,9).“ 
stup desítek let od II. vatikánského koncilu pořád ještě částečně vězíme ve starých tradicích neteologických spekulací a neteologické poslušnosti.

Věrnost tradici víry znamená, že se držíme co nejvěrněji tradice víry církve, tedy víry přijaté od apoštolů a předávané po generace. Tato věrnost věřícího člověka zavazuje, aby tradici bral vážně a ctil a aby ji nezodpovědně nezlehčoval a nepopíral. Jeho kritika jednotlivých tvrzení předkládaných s odvoláním na tradici víry ovšem může být i výrazem jeho zodpovědného postoje proti lidským formulacím zatemňujícím Boží pravdu. ${ }^{42}$

Jsou ovšem i jiné tradice než tradice víry, i tradice teologického a filosofického myšlení, tradice myšlenkových schémat atd., které jsou také předávané z generace na generaci. To jsou však tradice lidského porozumění, nikoliv tradice Bohem zjevené a podnícené víry a u nich je třeba vždy zkoumat, nakolik jsou pravdivé a nakolik je jejich převzetí, tedy vždy kritické převzetí, poctivé. Ne všechny tradice jsou dobré, některých je třeba se držet, od některých je třeba se osvobodit, abychom svými tradicemi nerušili Boží slovo ${ }^{43}$ a abychom mohli i v teologii přinášet radostnou zvěst o svobodě, kterou nám dává Kristus, zvěstovat záchranu a radost a pomáhat lidem jít po cestě spásy. Od některých myšlenkových schémat je třeba se osvobodit v zájmu zachování pravdivě teologického postoje.

Libor Ovečka (1950), Katedra teologické etiky a spirituální teologie KTF UK

\section{ABSTRACT \\ LIBOR OVEČKA \\ When is Theological Ethics not Theological? \\ Problems in the Czech Tradition of Moral Theology}

The article questions real theological character of some streams of the older Czech moral theological thought which ended in 1948 (beginning of the communist regime) and after 1989 has never been quoted or mentioned. It was a rationalistic neo-scholastic period of abstract philosophical theology.

42 Morální příručky uváděly mezi hříchy proti víře i dobrovolnou pochybnost o víře, např. URBAN, Jan Ev. Ućeni viry pro vstup dospélých do Církve Kristovy. Praha: Bohuslav Rupp, 1946, s. 224: „V I. přikázání se poroučí: Víra v Boha, v jeho zjevení, které Církev katolická k věření předkládá.“ Hřích pochybnosti o víře by ovšem mohl existovat jen jako výraz nezodpovědného a nepřemýšlejícího postoje. Člověk zodpovědný a přemýšlející tímto svým postojem nemůže hřešit, i kdyby jej dovedl k odmítnutí některých článků víry.

43 Srov. Mk 7,13. 
The blind alleys of theology can be traced in such areas as: the Scripture and philosophical speculation; "good" deed being good only as resulting in one's eternal happiness; personal spiritual life and universally binding moral norms; moral norms and the church and state law; natural ethics; dependence of theology on the political situation; universal validity and particular character of catholic moral theology; moral and religious norms of acting; moral responsibility to one's conscience and ethical responsibility to a heteronomous authority.

As examples of a really theological moral theology the work of Thomas Aquinas and Franz Böckle are presented. Their rationally constructed theology may be opposed by legal or disciplinary measures, religious manipulation, direct arguing by the will of God, or blind obedience. Nevertheless, personal moral responsibility remains undisputed. It is necessary to free oneself from some thought patterns and false traditions to uphold responsibility to the tradition of faith and real theology.

Key words

theological ethics, moral theology, Czech history before 1948, neo-scholasticism, blind alleys of theology, conscience, personal moral responsibility 